\title{
SPOŁECZEŃSTWO OBYWATELSKIE W POLSCE 25 LAT PO WIELKIEJ ZMIANIE
}

\section{IDEA SPOLECZEŃSTWA OBYWATELSKIEGO}

Pojęcie „społeczeństwo obywatelskie” (civil society), jak większość pojęć w naukach społecznych, jest nieostre i uwikłane ideologicznie. Tym bardziej że - jak zwraca uwagę autorka pracy o współczesnej debacie nad ideą społeczeństwa obywatelskiego Dorota Pietrzyk-Reeves - współcześnie funkcjonuje ono w co najmniej trzech różnych językach: w języku polityki, w języku filozofii i wreszcie, w języku socjologii. W dwóch pierwszych pojęcie „społeczeństwo obywatelskie" ma charakter normatywny ${ }^{1}$.

Dla polityka jest sloganem propagandowym, dla filozofa polityki - modelem ustrojowym. Społeczeństwo obywatelskie rozumiane jako model ustrojowy wywodzi się przy tym z dwóch odmiennych filozofii politycznych. Z jednej strony ze zorientowanej na wspólnotę tradycji republikańskiej definiującej obywatelstwo poprzez prawa i obowiązki, z drugiej - z podkreślającej rolę jednostki tradycji liberalnej, koncentrującej się przede wszystkim na prawach obywatelskich $^{2}$. Debata filozoficzna nad społeczeństwem obywatelskim jest tak stara jak refleksja nad państwem i społeczeństwem. Literatura poświęcona społeczeństwu obywatelskiemu jako modelowi ustrojowemu jest ogromna i zróżnicowana.

Dla socjologa z kolei pojęcie społeczeństwa obywatelskiego ma przede wszystkim charakter opisowy, ma służyć diagnozie stanu systemu społecznego. Definicje socjologiczne społeczeństwa obywatelskiego najczęściej wyliczaja te działania, które dany autor uznaje za konstytuujące tę sferę życia publicznego. Pietrzyk-Reeves wyróżnia dwudzielną i trójdzielną tradycję myślenia o społeczeństwie obywatelskim. Dwudzielny model społeczeństwa obywatelskiego propagowany współcześnie m.in. przez Johna Keyna i Ernesta Gellnera, sięgający zaś korzeniami Johna Locke'a, Georga W. F. Hegla i Karola Marksa, przeciwstawia je wyłącznie państwu, a za istotę społeczeństwa

${ }^{1}$ D. Pietrzyk-Reeves, Idea społeczeństwa obywatelskiego. Wspótczesna debata i jej źródta, Monografie Fundacji na rzecz Nauki Polskiej, Wrocław 2004.

${ }^{2}$ Ibidem. 
obywatelskiego uznaje gospodarkę. Z kolei model trójdzielny nawiązujący do Alexisa de Tocqueville'a i Antonia Gramsciego przeciwstawia społeczeństwo obywatelskie obu wymienionym sferom: zarówno państwu, jak i gospodarce. Najwybitniejsi współcześni przedstawiciele tego kierunku to Jürgen Habermas, Jean Cohen i Andrew Arato. Dwaj ostatni ze sfery społeczeństwa obywatelskiego wyłączaja przy tym nie tylko państwo i gospodarkę, lecz także cała sferę polityczna, z partiami politycznymi włącznie. Niektórzy autorzy ida jeszcze dalej i wykluczają z tej kategorii także organizacje religijne.

Współcześnie ideami bliskimi społeczeństwa obywatelskiego są idee demokracji uczestniczacej (partycypacyjnej) czy tzw. trzeciego sektora.

Teoretyk demokracji Giovanni Sartori wyróżnia pięć rodzajów demokracji. Pierwszy rodzaj to de mokracja bezpośrednia, czyli sa morządna. Drugi wymieniony przezeń typ to demokracja przez referendum, będąca faktycznie szczególnym przypadkiem demokracji bezpośredniej. Trzeci rodzaj to demokracja wyborcza, a czwarty stanowi demokracja przedstawicielska (pośrednia), która z reguły łączy się z demokracją wyborcza, ale możliwa jest również demokracja przedstawicielska, w której przedstawiciele nie są powoływani w drodze wyborów. Piąty wyróżniony przez Sartoriego typ demokracji to demokracja partycypacyjna, oparta na dobrowolnym osobistym udziale w życiu publicznym, traktowanym jako akt znaczący, autentyczny i rzeczywisty ${ }^{3}$. Sartori nie uznaje przy tym udziału w wyborach za akt partycypacji. „Uczestnictwo właściwie i sensownie rozumiane polega na osobistym udziale, aktywnym i chętnym włączaniu się. Uczestnictwo nie jest więc prozaicznym »byciem częścią czegoś» [...], a tym bardziej przymusowym "włączeniem do czegoś». Uczestnictwo to ruch samoistny, dokładne przeciwieństwo bycia włączonym w ruch (z cudzej woli) czy przeciwieństwo zmobilizowania" ${ }^{4}$. Zdaniem Sartoriego tak rozumiane uczestnictwo może występować tylko w małych społecznościach, a utopijne jest oczekiwanie, że opierać się na nim może społeczeństwo globalne.

Również inny teoretyk demokracji David Held wśród 13 wyróżnionych przezeń modeli demokracji ( 6 klasycznych, 5 współczesnych, 2 przyszłościowe) jedynie 4 wiąże z aktywnym uczestnictwem obywateli: de mokrację rozwojową (wśród modeli klasycznych), demokrację deliberatywną (wśród modeli współczesnych) oraz demokratyczną autonomię i demokrację kosmopolityczną (czyli oba modele przyszłościowe) $)^{5}$.

Jak widzimy zatem, możliwa jest, a przynajmniej do tej pory była, demokracja bez społeczeństwa obywatelskiego, bez aktywnego uczestnictwa obywateli.

Inne bliskoznaczne społeczeństwu obywatelskiemu pojęcie to „trzeci sektor". Używane jest ono w przeciwstawieniu do sektora pierwszego (administracja) i drugiego (rynek). Obejmuje ono wtedy wszelkie stowarzyszenia, organizacje itp., które określa się także dwoma innymi nazwami: non-govermental (NGO) i non profit. Mniej sformalizowane działania, np. sasiedzkie,

\footnotetext{
${ }^{3}$ G. Sartori, Teoria demokracji, WN PWN, Warszawa 1994.

${ }^{4}$ Ibidem, s. 148.

${ }^{5}$ D. Held, Modele demokracji, Wyd. UJ, Kraków 2010.
} 
nazywa się czasami mianem „czwartego sektora”. Określenie „sektor” ma mniej filozoficzne, a bardziej ekonomiczne i biurokratyczne konotacje niż „społeczeństwo obywatelskie”.

Zarówno teoretycy, jak i badacze społeczeństwa cywilnego różnią się zatem w wielu kwestiach. Rozmaicie definiuja zakres zjawiska. Przypisuja mu różnorodne funkcje i znaczenie. Inaczej postrzegają znaczenie społeczeństwa obywatelskiego dla demokracji i jako czynnika zmiany społecznej. Nawet jednak ci autorzy, którzy nie traktuja społeczeństwa obywatelskiego ani jako niezbędnego warunku demokracji, ani jako kluczowego obecnie mechanizmu demokratyzacji państw totalitarnych czy autorytarnych, uznają zasadniczo rozwój społeczeństwa obywatelskiego za wartość, za stan pożądany. Poprzez swobodne zrzeszanie się i współdziałanie ludzie uczą się demokratycznych procedur, maja możność wpływania na sprawy publiczne, rozwiąywania problemów, którym nie jest w stanie stawić czoła ani państwo, ani rynek, tym bardziej samotna jednostka. Oczywiście nie każda aktywność publiczna ani też nie każde stowarzyszenie służą demokracji czy wspólnemu dobru. Wiele działań oddolnych może realizować bardzo partykularne interesy, dysfunkcjonalne z punktu widzenia szerszej zbiorowości. Taki charakter mają działania opisywane w literaturze mianem syndromu NIMBY (Not in my back yard). Ten typ działań był szczególnie częsty w naszym kraju w początkach lat dziewięćdziesiątych, np. w postaci protestów przeciwko lokalizacji ośrodków dla osób zarażonych wirusem HIV. Podobnie nie służą demokracji stowarzyszenia o charakterze wyłącznie nepotycznym, wspierajace kariery swoich członków. Być może najbardziej znanym polskim przykładem jest stowarzyszenie „Ordynacka”. Z kolei pewna część fundacji i stowarzyszeń w naszym kraju powołana została tylko po to, aby ominąć przepisy podatkowe lub za granty unijne uprawiać działania pozorne, jak np. wiele organizacji szkoleniowych. Wreszcie, niektóre ze stowarzyszeń obywatelskich, np. amerykański Ku-Klux-Klan, są organizacjami wręcz zbrodniczymi. Jak widać z tych przykładów, oddolne stowarzyszanie się i wspólne działanie nie jest wartością samą w sobie.

W tekście tym przyjmuję stosunkowo szeroka definicję społeczeństwa obywatelskiego zaproponowaną przez Center for Civil Society przy London School of Economics:

Pojęcie „społeczeństwo obywatelskie” odnosi się do sfery dobrowolnych zbiorowych działań zorganizowanych wokół wspólnych interesów, celów lub wartości. Teoretycznie jego zinstytucjonalizowane formy są czymś odmiennym od działań podejmowanych przez państwo, rodzinę czy rynek, w praktyce jednak granice między państwem, społeczeństwem obywatelskim, rodziną i rynkiem są często niejasne, zamazane i płynne. Społeczeństwo obywatelskie na ogół obejmuje różnorodne przestrzenie, podmioty i instytucjonalne formy, różniące się stopniem sformalizowania, autonomii i posiadanej władzy. Społeczeństwa obywatelskie często są wypełnione takimi organizacjami, jak zarejestrowane organizacje dobroczynne, rozwijające się organizacje pozarządowe, grupy lokalne, organizacje kobiece, wyznaniowe, stowarzyszenia zawodowe, związki zawodowe, organizacje samopomocowe, ruchy społeczne, stowarzyszenia przedsiębiorców, związki i grupy poparcia $(\text { advocacy })^{6}$.

${ }^{6} \mathrm{Http}: / /$ www.lse.ac.uk/collections/CCS/what_is_civil_society.htm), tłum. własne. 


\section{CZY POLACY POTRAFIĄ STWORZYĆ SPOŁECZEŃSTWO OBYWATELSKIE?}

W polskiej debacie publicznej dominuje przekonanie, że społeczeństwo obywatelskie jest w Polsce wyjątkowo słabe. Taką opinię, bodajże jako pierwszy, wyraził już w 1862 r. Cyprian Kamil Norwid w liście do swojej znajomej Michaliny z Dziekońskich Zaleskiej. Przytaczam tu obszerniejszy, niż na ogół się czyni, fragment jego słynnej wypowiedzi na ten temat. Jak bowiem sądzę, refleksja poety pozwala na trafniejszą interpretację także współczesnych zjawisk w naszym kraju. Norwid nie posługuje się co prawda pojęciem społeczeństwa obywatelskiego, ale bliskim mu znaczeniowo pojęciem „społeczeństwa” jako formy zbiorowości przeciwstawionej „narodowi”.

Oto jest społeczność polska! społeczność narodu, który nie zaprzeczam, iż o tyle jako patriotyzm wielki jest, o ile jako społeczeństwo jest żaden. Wszystko, co patriotyzmu i historycznego dotyczy uczucia, tak wielkie i wielmożne jest w narodzie tym, iż zaiste, że kapelusz zdejmam przed ulicznikiem warszawskim - ale - ale wszystko to, czego nie od patriotyzmu, czego nie od narodowego, ale czego od społecznego uczucia wymaga się, to jest tak początkujące, małe i prawie nikczemne, że strach wspominać o tym! [...] Jesteśmy żadnym społeczeństwem. Jesteśmy wielkim sztandarem narodowym.

Może powieszą mię kiedyś ludzie serdeczni za te prawdy, których istotę powtarzam lat około dwanaście, ale gdybym miał dziś na szyi powróz, to jeszcze gardłem przywartym chrypiałbym, że Polska jest ostatnie na globie społeczeństwo, a pierwszy na planecie naród. Kto zaś jedną nogę ma długą jak oś globowa, a drugiej nogi wcale nie ma, ten, o! jakże ułomny kaleka jest! $!^{7}$

Zwracam uwagę, że wypowiedź ta poprzedza o parę miesięcy wybuch powstania styczniowego, czyli kolejnej wielkiej mobilizacji narodowej.

Używając innego języka, podobny obraz Polaków przeszło 100 lat później rysował socjolog Stefan Nowak. Rok przed kolejnym, tym razem zresztą także, ale nie tylko narodowym, zrywem w katalogu do znanej wystawy „Polaków portret własny” postawił on tezę o istnieniu w Polsce „socjologicznej próżni”. Jak zauważył:

[...] pomiędzy poziomem pierwotnych grup i poziomem społeczności istnieje, z punktu widzenia ludzi i ich emocjonalnego zaangażowania - rodzaj socjologicznej próżni. [...] społeczna struktura naszego kraju jawiłaby się jako „federacja” grup pierwotnych, rodzin i grup opartych na przyjaźni, zjednoczonych w narodowej wspólnocie z bardzo słabymi innymi typami więzi pomiędzy tymi dwoma poziomami. [...] Pojęcie „oni” wyraża emocjonalny dystans lub wręcz niechęć pomiędzy „światem ludzi” i „światem instytucji”, wyraża przekonanie że instytucje są często postrzegane jako nieprzyjazne, niechętne, nierzetelne, a czasem wręcz zagrażające $^{9}$.

${ }^{7}$ C. K. Norwid, Z listu do Michaliny z Dziekońskich Zaleskiej [st. poczt. 14 XI 1862], http:// www.pbi.edu.pl/book_reader.php?p=5099.

${ }^{8}$ S. Nowak, Przekonania i odczucia wspótczesnych, w: Polaków portret własny, Wydawnictwo Literackie, Kraków 1979.

${ }^{9}$ Idem, O Polsce i Polakach. Prace rozproszone 1958-1989, zebr. A. Sułek, Wyd. UW, Warszawa 2009 , s. $140-141$. 
Identyfikacja z rodzina i kręgiem przyjacielskim miała charakter praktyczno-codzienny, identyfikacja z narodem - odświętno-symboliczny. Naród przy tym nie był traktowany jako tożsamy z państwem. Pomiędzy tak rozumianym narodem a rodziną i kolegami nie istniały żadne zbiorowości nadające jednostce tożsamość i poczucie przynależności. Wyrażając tezę Nowaka w ,języku” społeczeństwa obywatelskiego, można by powiedzieć, że brakowi identyfikacji (emocjonalnemu odrzuceniu) z państwem towarzyszył kompletny brak z reguły przeciwstawianej mu sfery obywatelskiej.

$\mathrm{W}$ początkach naszego wieku w wolnej i demokratycznej Polsce o braku społeczeństwa obywatelskiego pisał Piotr Gliński, ówczesny kierownik Zakładu Społeczeństwa Obywatelskiego IFiS PAN:

To właśnie organizacje pozarządowe, różnorodne stowarzyszenia, fundacje, fundusze lokalne, kluby, wspólnoty obywateli decydują w znacznej mierze o demokracji, w istocie zaś o jakości naszego życia społecznego. Poprzez te właśnie struktury realizuje się w praktyce idea społeczeństwa obywatelskiego: wspólnoty wyręczającej państwo w realizacji ludzkich potrzeb i interesów i pozwalającej się ludziom różnić w sposób cywilizowany, społeczeństwa prawdziwie wolnego i tolerancyjnego, aktywnego i odpowiedzialnego, przyjaznego wszelkim mniejszościom, słabym i utalentowanym, pracowitym i zagubionym, a przede wszystkim madrego i rzetelnego w trosce o dobro publiczne. Wykształcenie społeczeństw o takich właśnie cechach, społeczeństwa prawdziwie obywatelskiego było jednym z trzech - obok budowy instytucji demokracji przedstawicielskiej i rynku ekonomicznego - głównych postulowanych celów polskiej transformacji. Niestety, cel ten zrealizowany został chyba w najmniejszym stopniu ze wszystkich zamierzeń i planów transformacyjnych [...] ta swoista słabość polskiego społeczeństwa obywatelskiego powoduje szereg istotnych kłopotów i trudności w naszym życiu społecznym; jest źródłem wielu problemów życia codziennego Polaków i współdecyduje o złej jakości polskiej demokracji ${ }^{10}$.

Co znaczące, niemal bezpośrednio z tezą Nowaka o „próżni socjologicznej” współbrzmi opublikowana 34 lata później ugruntowana empirycznie opinia Anny Gizy o nieobecności w „społecznym lustrze”, jakim jest telewizja, sfery społecznej:

Instytucje publiczne są [...] raczej zagrożeniem niż wsparciem dla ludzi. Prawdziwego i niezawodnego wsparcia dostarczają natomiast małe kręgi społeczne [...] o prywatnym charakterze. W telewizji nie ma „społeczeństwa” - działaczy społecznych, organizacji społecznych, wspólnych inicjatyw podejmowanych przez sieci społeczne. [...] ujawniajacca się od czasu do czasu zdolność Polaków do samoorganizacji stanowi niezmiennie przedmiot zadziwienia mediów: wystarczy przypomnieć znane przypadki protestów przeciw ACTA czy zachowania kibiców w czasie Euro 2012. Świat telewizyjny pozostaje „federacją rodzin”, funkcjonujących w izolacji od „systemu”. [...] Jednocześnie trzeba podkreślić, że negatywny wizerunek sfery publicznej dostarcza znakomitego usprawiedliwienia dla uchylania się od zobowiązań na rzecz dobra wspólnego. [...] Społeczeństwo, które nie zna swoich instytucji publicznych i społecznych i jednocześnie ma uogólniony negatywny stosunek do najważniejszych spośród nich, nie może stać się bardziej obywatelskie ${ }^{11}$.

${ }^{10}$ P. Gliński (red.), Samoorganizacja społeczeństwa polskiego: trzeci sektor, Wyd. IFiS, Warszawa 2002, s. 5-6.

${ }^{11}$ A. Giza, Spoteczeństwo przed telewizorem, czyli co widać w ramówce, w: eadem (red.), Gabinet luster. O ksztattowaniu samowiedzy Polaków w dyskursie publicznym, Scholar, Warszawa 2013, s. 277-278. 
Krytyczne opinie o braku polskiego społeczeństwa obywatelskiego nie dotyczą całych dziejów nowożytnych. Bywały historyczne sytuacje, w których przejawiało się ono w sposób unikatowy. Tak było w czasie II wojny światowej, gdy powstało w naszym kraju Polskie Państwo Podziemne. Były to alternatywne wobec okupacyjnych struktury nie tylko polityczne i militarne, lecz także sądowe, samopomocowe, edukacyjne i kulturalne, ba, nawet naukowe. Istniał podziemny rząd, siły zbrojne, sądy, szkolnictwo, życie kulturalne, organizacje społeczne. Przeprowadzano nawet badania socjologiczne, w tym badanie postaw i wartości ok. 300 młodych ludzi należących do Szarych Szeregów. Polskie Państwo Podziemne było w istocie bardzo szczególną formą społeczeństwa obywatelskiego. Jak pisał Jan Szczepański:

\begin{abstract}
Polska jako jedyna kontynuowała swój byt państwowy w postaci państwa podziemnego. Jest to, moim zdaniem, daleko większy powód do chluby niż zniszczenie Warszawy w beznadziejnym powstaniu. W ten sposób bowiem Polska do stworzenia państwa w warunkach najtrudniejszych, zademonstrowała swoja zdolność do rozbudowania jego instytucji, objęcia swym działaniem prawie wszystkich zakresów cywilnego życia narodu, ratowania substancji gospodarczej, społecznej i kulturalnej. A to wymagało godnych podziwu umiejętności, twórczych metod pracy i dyscypliny społecznej [...] państwo podziemne jest najdonioślejszym argumentem w zwalczaniu hitlerowskiej propagandy przedstawiającej naród polski jako Untermenschen niezdolnych do zorganizowania [...] swojego życia zbiorowego [...] tworząc państwo podziemne naród ten wykazał, że to wszystko potrafi ${ }^{12}$.
\end{abstract}

Inny przykład to powstała w drugiej połowie lat siedemdziesiątych ubiegłego wieku demokratyczna opozycja. Przywódca jej najbardziej znaczącego odłamu - Jacek Kuroń rzucił hasło, które było kwintesencją idei społeczeństwa obywatelskiego: „Zamiast palić komitety, zakładajcie własne!”. Parę lat później powstał NSZZ „Solidarność”, masowy ruch społeczno-narodowo-pracowniczy, który na kilkanaście miesięcy wypełnił polską „,socjologiczną próżnię”. To dzięki „Solidarności” wielu socjologów i filozofów, w tym m.in. Arato i Cohen z New School for Social Research, powróciło do zapomnianej już nieco kategorii społeczeństwa obywatelskiego. Przyjęty przez zjazd „Solidarności” w 1981 r. program budowy „Rzeczypospolitej Samorządnej” był nieco utopijną wizją budowy państwa opartego na społeczeństwie obywatelskim. Ta koncepcja nawiązywała zreszta do idei polskiego filozofa, socjologa i psychologa Edwarda Abramowskiego, który u schyłku zaborów wzywał do „zmowy powszechnej przeciwko rządowi” i przeciwstawienia mu „społeczeństwa kooperatywnego"13. Wieloma inicjatywami obywatelskimi zaowocował również stan wojenny. Idee społeczeństwa obywatelskiego z uporem lansował Stefan Bratkowski w periodyku „Niewidomy Spółdzielca”, „Tygodniku Powszechnym” czy w serialu Najdtuższa wojna nowoczesnej Europy. W 1989 r. PRL-owska „próżnia społeczna" została wypełniona po raz drugi, tym razem przez ruch komitetów

12 J. Szczepański, Niektóre aspekty funkcjonowania państwa podziemnego, Przedmowa, w: Wobec czasów pogardy, antologia tekstów pod red. L. Sobierajskiego, LSW, Warszawa 1988, s. 6-7.

${ }^{13}$ E. Abramowski, Rzeczpospolita przyjaciót. Wybór pism społecznych i politycznych, oprac. D. Kalbarczyk, IW PAX, Warszawa 1986. 
obywatelskich. O ile w latach 1980-1981 integracja społeczna dokonywała się w zakładach pracy, o tyle w 1989 r. jej miejscem były miejscowości, dzielnice, osiedla. „Solidarność” przełomu lat osiemdziesiątych i dziewięćdziesiątych była już nie solidarnością pracowników, lecz mieszkańców, obywateli.

\section{POLSKIE SPOLECZEŃSTWO OBYWATELSKIE PO ROKU 1989 W ŚWIETLE BADAŃ}

Jeżeli bez względu na teoretyczne kontrowersje wokół samego pojęcia rozwój społeczeństwa obywatelskiego jest zasadniczo uznawany za pożądany, to w debacie nad Polska w 25 lat po wyborach 4 czerwca 1989 r. warto zastanowić się nad tym, jak ten trzeci, obok demokracji parlamentarnej i wolnego rynku, filar demokracji u nas funkcjonuje.

Odwołam się tu do wybranych badań, przede wszystkich takich, które umożliwiają porównanie stanu społeczeństwa obywatelskiego w Polsce z sytuacją w innych krajach, głównie europejskich (World Values Survey, European Values Studies, European Social Survey, Eurobarometer), oraz takich, które pokazuja ewolucję polskiego społeczeństwa obywatelskiego w ostatnim ćwierćwieczu (badania CBOS-u Diagnoza społeczna).

\section{Badania porównawcze: Polska na tle innych krajów}

Kluczowym elementem społeczeństwa obywatelskiego jest stowarzyszanie się, współdziałanie, uczestnictwo w życiu publicznym. Większość omawianych tu, z konieczności w wielkim skrócie, badan tych zatem kwestii dotyczy.

Badania World Values Survey (WVS) z 1990 r. i European Values Survey (EVS) z 1999 r. pokazuja, po pierwsze, że przynależność do stowarzyszeń różnego typu oraz aktywność obywatelska w ciagu pierwszej dekady transformacji malała. Było to oczywiście skutkiem specyfiki organizacji społecznych w PRL, często jedynie pozorujących działalność, do których przynależność była jeśli nie przymusowa, to przynajmniej „dobrze widziana”. W każdym razie odsetek Polaków nigdzie nienależących zwiększył się z 54,7 do $75 \%$, a niepodejmujacych żadnych działań na rzecz wspólnoty wzrósł z 66,4 do $86,1 \%$. Po drugie, badanie to pokazuje, że u schyłku ubiegłego wieku obywatelska aktywność Polaków pozostawała poniżej średniej europejskiej. Szczególnie widoczne to było w przypadku przynależności do związków zawodowych, do organizacji religijnych i sportowych. O ile w Europie ogółem do żadnego stowarzyszenia nie należało 51,2\%, o tyle w Polsce odsetek ten wynosił, jak już wspomniano, aż $75 \%$. Znajacc polskie realia kulturowe, nie może dziwić niskie, niemal śladowe zaangażowanie w działania organizacji ekologicznych, kobiecych czy na rzecz Trzeciego Świata. Dziwić może natomiast fakt, że do organizacji o charakterze religijnym należało w $1999 \mathrm{r}$. w katolickiej Polsce niemal trzykrotnie mniej obywateli niż w znacznie bardziej laickiej Europie. 


\section{Tabela 1}

Aktywność społeczna w Polsce w porównaniu ze „średnią europejską" (badanie EVS, 29 krajów, 1999 r. oraz dane dla Polski z badania WVS, 1990 r.)

\begin{tabular}{|c|c|c|c|c|c|c|}
\hline \multirow{3}{*}{ Typ organizacji } & \multirow{2}{*}{\multicolumn{2}{|c|}{$\begin{array}{c}\begin{array}{c}\text { Bycie członkiem } \\
{[\%]}\end{array} \\
\text { Polska }\end{array}$}} & \multirow{3}{*}{$\begin{array}{c}\begin{array}{c}\text { Średnia } \\
\text { dla } \\
\text { Europy } \\
{[\%]}\end{array} \\
1999\end{array}$} & \multirow{2}{*}{\multicolumn{2}{|c|}{$\begin{array}{c}\begin{array}{c}\text { Działanie na } \\
\text { rzecz [\%] }\end{array} \\
\text { Polska }\end{array}$}} & \multirow{3}{*}{$\begin{array}{c}\begin{array}{c}\text { Średnia } \\
\text { dla } \\
\text { Europy } \\
\text { [\%] }\end{array} \\
1999\end{array}$} \\
\hline & & & & & & \\
\hline & 1990 & 1999 & & 1990 & 1999 & \\
\hline Kobiece & 4,8 & 1,2 & 2,5 & 2,4 & 0,5 & 1,3 \\
\hline Kulturalne & 2,1 & 2,2 & 9,6 & 2,0 & 1,7 & 4,8 \\
\hline Lokalne pomocowe & 2,4 & 1,7 & 3,0 & 2,1 & 1,4 & 2,0 \\
\hline Młodzieżowe & 2,8 & 1,6 & 3,8 & 2,1 & 0,7 & 2,9 \\
\hline $\begin{array}{l}\text { Na rzecz rozwoju Trzeciego } \\
\text { Świata }\end{array}$ & 0,2 & 0,4 & 3,1 & 0,5 & 0,1 & 1,3 \\
\hline Ochrony środowiska & 1,9 & 1,3 & 4,8 & 1,7 & 0,5 & 1,9 \\
\hline $\begin{array}{l}\text { Partie lub stowarzyszenia } \\
\text { polityczne }\end{array}$ & 1,6 & 0,7 & 4,3 & 0,8 & 0,5 & 1,9 \\
\hline Pomocy społecznej & 2,7 & 3,0 & 6,1 & 5,0 & 2,2 & 3,9 \\
\hline Prozdrowotne & 1,6 & 1,5 & 3,5 & 1,6 & 0,6 & 2,3 \\
\hline Religijne lub kościelne & 7,0 & 5,7 & 14,0 & 9,4 & 3,7 & 5,8 \\
\hline Ruchy pokojowe & 0,2 & 0,5 & 1,0 & 0,1 & - & 0,7 \\
\hline Sportowe & 4,7 & 3,1 & 15,6 & 3,0 & 2,2 & 6,6 \\
\hline Zawodowe, profesjonalne & 4,0 & 4,4 & 5,3 & 1,9 & 1,3 & 1,9 \\
\hline Związki zawodowe & 21,3 & 10,3 & 16,7 & 5,5 & 2,3 & 2,8 \\
\hline Inne & 3,0 & 2,7 & 5,8 & 2,8 & 2,1 & 3,5 \\
\hline Nie należy (nie zrobił niczego) & 54,7 & 75,0 & 51,2 & 66,4 & 86,1 & 71,2 \\
\hline
\end{tabular}

Źródło: M. Marody, Przemiany religijności Polaków, w: A. Jasińska-Kania, M. Marody (red.), Polacy wśród Europejczyków, Scholar, Warszawa 2002, s. 160.

W różnych krajach odsetek osób należących do rozmaitych stowarzyszeń był bardzo zróżnicowany. Według badań WVS z 1990 r. ${ }^{14}$ oraz EVS z 1999 r..$^{15}$ największy odsetek mieszkańców (aż 80-90\%) stowarzyszał się w krajach skandynawskich, Holandii i USA. Przeszło połowa mieszkańców należała też do jakichś stowarzyszeń w zachodniej części Niemiec, Kanadzie, Austrii, Belgii, Wielkiej Brytanii. Poniżej połowy populacji zrzeszało się we Francji, Włoszech, Japonii. W poszczególnych społeczeństwach różne stowarzyszenia cieszą się różną popularnością. W USA (połowa) i Kanadzie (jedna czwarta)

${ }_{14}$ T. Szawiel, Społeczeństwo obywatelskie, w: M. Grabowska, T. Szawiel, Budowanie demokracji. Podziały społeczne, partie polityczne i społeczeństwo obywatelskie $w$ postkomunistycznej Polsce, WN PWN, Warszawa 2003.

${ }_{15}$ M. Marody, op. cit.; J. Bartkowski, A. Jasińska-Kania, Organizacje dobrowolne a rozwój społeczeństwa obywatelskiego, w: A. Jasińska-Kania, M. Marody (red.), op. cit. 
najwięcej osób należy do organizacji religijnych. Inaczej wygląda to w Europie, gdzie najbardziej masowy charakter maja stowarzyszenia sportowo-rekreacyjne. W zachodniej części Niemiec należy do nich co trzeci dorosły, w Anglii i Francji - co siódmy. Także w USA i Kanadzie stowarzyszenia sportowo-rekreacyjne zrzeszają co czwartego obywatela. Na trzecim miejscu sytuują się dopiero związki zawodowe. Taka kolejność odzwierciedla oczywiście zmiany w hierarchii wartości i strukturze czasu społecznego, jakie dokonały się w cywilizacji zachodniej w ostatnich latach. Na dalszych miejscach sytuują się partie polityczne, organizacje kobiece, ekologiczne, stowarzyszenia profesjonalne, grupy pomocy społecznej. Do wymienionych form zrzeszania się należy (poza USA i Kanada) jedynie kilka procent obywateli.

Z kolei autorzy badania European Social Survey (ESS) z lat 2002-2003 ${ }^{16}$ wyróżnili pięć grup krajów europejskich z punktu widzenia stopnia rozwoju społeczeństwa obywatelskiego. Najwyższy odsetek obywateli należy do jakichś stowarzyszeń w krajach „nordyckich” (80,3\%), następnie w krajach „liberalnych” (72,3\%) i „konserwatywnych” (62,5\%), a najmniej w krajach „śródziemnomorskich” (39,2\%) i „postkomunistycznych” (18,3\%). Dane zawarte w tabeli 2 pokazuja, że w każdej z analizowanych kategorii na ostatnich miejscach, obok peryferyjnych społeczeństw Południa (Portugalii i Grecji), znajduja się Polska i Węgry (inne społeczeństwa postkomunistyczne nie były objęte tym badaniem).

Tabela 2

Członkostwo w różnych organizacjach społecznych w 20 krajach Europy, lata 2002-2003, ESS [\%]

\begin{tabular}{|c|c|c|c|}
\hline $\begin{array}{c}\text { Rodzaj } \\
\text { stowarzyszenia }\end{array}$ & $\begin{array}{c}\text { Ogółem } \\
20 \text { krajów [\%] }\end{array}$ & $\begin{array}{c}\text { Kraje o najwyższym } \\
\text { uczestnictwie [\%] }\end{array}$ & $\begin{array}{c}\text { Kraje o najniższym } \\
\text { uczestnictwie [\%] }\end{array}$ \\
\hline Jakiekolwiek & 53,5 & $\begin{array}{r}\text { Holandia }-83,8 \\
\text { Szwecja }-83,7 \\
\text { Dania }-81,7\end{array}$ & $\begin{array}{r}\text { Polska - 19,1 } \\
\text { Grecja - 21,0 } \\
\text { Węgry - 28,8 }\end{array}$ \\
\hline Asocjacyjne & 47,1 & $\begin{array}{r}\text { Holandia }-73,6 \\
\text { Dania }-72,5 \\
\text { Szwecja }-71,5\end{array}$ & $\begin{array}{r}\text { Grecja - 15,2 } \\
\text { Polska - 15,7 } \\
\text { Węgry }-24,4\end{array}$ \\
\hline Zawodowe & 26,3 & $\begin{array}{r}\text { Dania }-68,7 \\
\text { Szwecja }-60,5 \\
\text { Finlandia }-55,7\end{array}$ & $\begin{array}{r}\text { Polska - } \mathbf{8 , 1} \\
\text { Portugalia - } 8,3 \\
\text { Węgry - } 10,2\end{array}$ \\
\hline Humanitarne & 17,2 & $\begin{array}{r}\text { Holandia }-31,7 \\
\text { Austria }-30,6 \\
\text { Szwecja }-28,6\end{array}$ & $\begin{array}{r}\text { Polska - } \mathbf{4 , 1} \\
\text { Grecja - 5,7 } \\
\text { Węgry - 5,9 }\end{array}$ \\
\hline Konsumenckie & 16,6 & $\begin{array}{r}\text { Luksemburg }-45,9 \\
\text { Szwecja }-37,7 \\
\text { Norwegia }-36,6\end{array}$ & $\begin{array}{r}\text { Grecja - } 0,5 \\
\text { Polska - } \mathbf{0 , 6} \\
\text { Węgry - } 3,2\end{array}$ \\
\hline
\end{tabular}

Źródło: H. Domański, Społeczeństwo europejskie. Stratyfikacja i system wartości, Scholar, Warszawa 2009, s. 171.

${ }^{16}$ H. Domański, op. cit. 
Tabela 3

Uczestnictwo w jakichkolwiek działaniach stowarzyszeń, młodzież (15-30 lat), 28 krajów (UE + Chorwacja), 2013, Eurobarometer

\begin{tabular}{|c|c|c|c|c|}
\hline $\begin{array}{c}\text { Rodzaj } \\
\text { stowarzyszenia }\end{array}$ & $\begin{array}{l}\text { Ogółem } \\
28 \text { krajów } \\
\text { UE [\%] }\end{array}$ & $\begin{array}{c}\text { Polska } \\
\text { [\%] }\end{array}$ & $\begin{array}{c}\text { Kraje o najwyższym } \\
\text { uczestnictwie [\%] }\end{array}$ & $\begin{array}{c}\text { Kraje o najniższym } \\
\text { uczestnictwie [\%] }\end{array}$ \\
\hline Klub sportowy & 35 & 19 & $\begin{aligned} & \text { Holandia }-50 \\
& \text { Irlandia }-53 \\
& \text { Szwecja, Luksemburg }-48 \\
&\end{aligned}$ & $\begin{aligned} & \text { Rumunia }-16 \\
& \text { Polska }-\mathbf{1 8} \\
& \text { Chorwacja }-20 \\
&\end{aligned}$ \\
\hline Czas wolny & 22 & 13 & $\begin{aligned} \text { Luksemburg } & -38 \\
\text { Irlandia } & -37 \\
\text { Belgia } & -32\end{aligned}$ & $\begin{aligned} \text { Chorwacja, } & \\
\text { Rumunia } & -12 \\
\text { Polska } & -\mathbf{1 3} \\
\text { Estonia, Litwa } & -14\end{aligned}$ \\
\hline $\begin{array}{l}\text { Na rzecz } \\
\text { społeczności } \\
\text { lokalnej }\end{array}$ & 15 & 12 & $\begin{aligned} \text { Irlandia } & -36 \\
\text { Wielka Brytania } & -25 \\
\text { Luksemburg, } & \\
\text { Portugalia } & -21 \\
\text { Belgia } & -17\end{aligned}$ & $\begin{array}{r}\text { Cypr }-5 \\
\text { Chorwacja, } \\
\text { Rumunia }-8 \\
\text { Bułgaria, } \\
\text { Słowenia - } 9\end{array}$ \\
\hline Kultur & 14 & 10 & $\begin{array}{r}\text { Luksemburg }-25 \\
\text { Słowacja }-23 \\
\text { Belgia }-22 \\
\end{array}$ & $\begin{array}{r}\text { Chorwacja, Cypr }-7 \\
\text { Rumunia }-8\end{array}$ \\
\hline $\begin{array}{l}\text { Promujące } \\
\text { prawa } \\
\text { człowieka } \\
\text { i globalny } \\
\text { rozwój }\end{array}$ & 8 & 5 & 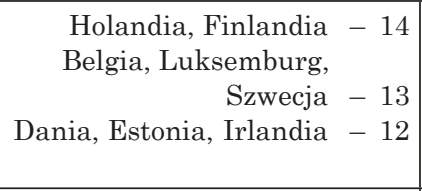 & $\begin{aligned} \text { Estonia } & -1 \\
\text { Litwa } & -2 \\
\text { Słowenia } & -3\end{aligned}$ \\
\hline $\begin{array}{l}\text { Ekologiczne, } \\
\text { zmiana klimatu }\end{array}$ & 7 & 1 & 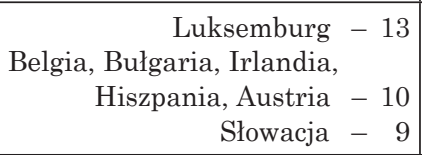 & $\begin{array}{r}\text { Polska }-1 \\
\text { Estonia, } \\
\text { Słowenia }-2 \\
\text { Chorwacja }-3\end{array}$ \\
\hline $\begin{array}{l}\text { Partia } \\
\text { polityczna }\end{array}$ & 5 & 2 & 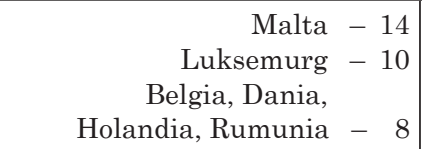 & $\begin{array}{r}\text { Węgry }-1 \\
\text { Polska, Czechy }-2 \\
\text { Estonia, } \\
\text { Słowenia }-3\end{array}$ \\
\hline Żadna & 44 & 60 & 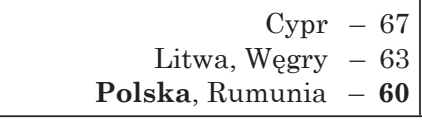 & $\begin{aligned} & \text { Holandia }-22 \\
& \text { Irlandia }-24 \\
& \text { Luksemburg }-25 \\
&\end{aligned}$ \\
\hline
\end{tabular}

Źródło: opracowanie własne na podstawie: Flash Eurobarometer 375, http://ec.europa.eu/public_opinion/ flash/fl_375_en.pdf.

Badania Eurequal przeprowadzone w 13 krajach Europy Środkowej i Wschodniej, w których uczestniczyłem jako kierownik polskiego zespołu, pokazały znaczne zróżnicowanie, gdy chodzi o przynależność do organizacji i stowarzyszeń. W niektórych z tych krajów, np. na Białorusi i w Mołdawii, stosunkowo wysoki wskaźnik uczestnictwa wynika najpewniej z niewielkiego zaawansowania procesów transformacyjnych. W innych, zwłaszcza w krajach bałtyckich, Czechach i na Słowacji - bardziej obywatelskiej kultury politycznej. Warto zauważyć, że nawet w tej grupie krajów Polska wyróżnia się niskim uczestnictwem w różnych formach stowarzyszania się. 


\section{Tabela 4}

Członkostwo w różnych organizacjach społecznych w 13 krajach Europy Środkowej i Wschodniej, 2007, projekt EUREQUAL, N=15 548

\begin{tabular}{|c|c|c|c|c|}
\hline $\begin{array}{c}\text { Rodzaj } \\
\text { stowarzyszenia }\end{array}$ & \begin{tabular}{|c|} 
Ogółem 13 \\
krajów Europy \\
Środkowej \\
i Wschodniej [\%] \\
\end{tabular} & $\begin{array}{c}\text { Polska } \\
{[\%]}\end{array}$ & $\begin{array}{l}\text { Kraje o najwyższym } \\
\text { uczestnictwie }\end{array}$ & $\begin{array}{l}\text { Kraje o najniższym } \\
\text { uczestnictwie }\end{array}$ \\
\hline $\begin{array}{l}\text { Stowarzyszenia } \\
\text { przedsiębiorców, izby } \\
\text { gospodarcze }\end{array}$ & 1,9 & 0,7 & $\begin{array}{l}\text { Mołdawia, Czechy, } \\
\text { Łotwa }\end{array}$ & $\begin{array}{l}\text { Polska, Bułgaria, } \\
\text { Rumunia, Estonia }\end{array}$ \\
\hline $\begin{array}{l}\text { Stowarzyszenia } \\
\text { zawodowe }\end{array}$ & 3,6 & 1,5 & $\begin{array}{l}\text { Białoruś, Mołdawia, } \\
\text { Łotwa }\end{array}$ & $\begin{array}{l}\text { Polska, Słowacja, } \\
\text { Bułgaria }\end{array}$ \\
\hline Związki zawodowe & 11,5 & 4,9 & $\begin{array}{l}\text { Białoruś, Słowacja, } \\
\text { Rosja }\end{array}$ & $\begin{array}{l}\text { Polska, Węgry, } \\
\text { Litwa }\end{array}$ \\
\hline Organizacje rolnicze & 1,9 & 1,3 & $\begin{array}{l}\text { Mołdawia, } \\
\text { Rumunia, Słowacja }\end{array}$ & $\begin{array}{l}\text { Bułgaria, Węgry, } \\
\text { Estonia }\end{array}$ \\
\hline $\begin{array}{l}\text { Organizacje } \\
\text { wyznaniowe }\end{array}$ & 6,2 & 3,3 & $\begin{array}{l}\text { Słowacja, Łotwa, } \\
\text { Litwa }\end{array}$ & $\begin{array}{l}\text { Rumunia, Bułgaria, } \\
\text { Rosja }\end{array}$ \\
\hline $\begin{array}{l}\text { Organizacje lokalne, } \\
\text { osiedlowe }\end{array}$ & 3,6 & 2,2 & $\begin{array}{l}\text { Litwa, Czechy, } \\
\text { Białoruś }\end{array}$ & $\begin{array}{l}\text { Bułgaria, Rumunia, } \\
\text { Łotwa }\end{array}$ \\
\hline Kluby sportowe & 6,2 & 2,9 & $\begin{array}{l}\text { Estonia, Czechy, } \\
\text { Słowacja }\end{array}$ & $\begin{array}{l}\text { Ukraina, Bułgaria, } \\
\text { Rumunia }\end{array}$ \\
\hline Partie polityczne & 2,6 & 0,6 & $\begin{array}{l}\text { Litwa, Czechy, } \\
\text { Słowacja }\end{array}$ & $\begin{array}{l}\text { Białoruś, Łotwa, } \\
\text { Polska }\end{array}$ \\
\hline $\begin{array}{l}\text { Organizacje } \\
\text { narodowe, etniczne }\end{array}$ & 0,6 & 0,3 & $\begin{array}{l}\text { Białoruś, Łotwa, } \\
\text { Słowacja, Rosja }\end{array}$ & $\begin{array}{l}\text { Węgry, Polska, } \\
\text { Mołdawia }\end{array}$ \\
\hline $\begin{array}{l}\text { Samorządy } \\
\text { w przedsiębiorstwach }\end{array}$ & 0,9 & 0,3 & $\begin{array}{l}\text { Białoruś, Słowacja, } \\
\text { Rosja }\end{array}$ & $\begin{array}{l}\text { Bułgaria, Węgry, } \\
\text { Polska, Czechy }\end{array}$ \\
\hline $\begin{array}{l}\text { Organizacje } \\
\text { pozarzadowe, } \\
\text { obywatelskie, ruchy } \\
\text { społeczne }\end{array}$ & 2,1 & 1,5 & $\begin{array}{l}\text { Słowacja, Czechy, } \\
\text { Litwa }\end{array}$ & $\begin{array}{l}\text { Rumunia, Bułgaria, } \\
\text { Polska, Rosja, } \\
\text { Białoruś }\end{array}$ \\
\hline $\begin{array}{l}\text { Samopomoc } \\
\text { sąsiedzka }\end{array}$ & 3,9 & 2,3 & $\begin{array}{l}\text { Litwa, Rumunia, } \\
\text { Estonia }\end{array}$ & $\begin{array}{l}\text { Bułgaria, Słowacja, } \\
\text { Węgry }\end{array}$ \\
\hline Inne & 4,4 & 3,2 & $\begin{array}{l}\text { Estonia, Litwa, } \\
\text { Czechy }\end{array}$ & $\begin{array}{l}\text { Mołdawia, Ukraina, } \\
\text { Rumunia }\end{array}$ \\
\hline
\end{tabular}

Źródło: badania własne.

Również w takich formach uczestnictwa w życiu publicznym, jak noszenie odznak czy nalepek „politycznych” lub podpisywanie petycji, w badaniach ESS w latach 2002-2006 Polska zajmowała końcowe miejsca wraz z innymi krajami postkomunistycznymi. Dla przykładu w 2006 r. podpisanie jakiejś petycji deklarowało: 5,1\% - Ukraińców, 5,4\% - Polaków, 5,7\% - Węgrów, podczas gdy uczyniło to 44,5\% - Szwedów, 40,6\% - Brytyjczyków, 37,6\% - Norwegów, $36,1 \%$ - Francuzów czy 27,5\% - Niemców ${ }^{17}$.

\footnotetext{
${ }^{17}$ H. Domański, op. cit.
} 
Najnowsze (z 2013 r.) badania porównawcze aktywności stowarzyszeniowej w Europie dotyczyły tylko najbardziej aktywnej kategorii - młodzieży. Również one pokazuja, że najmniej młodych ludzi działa społecznie w krajach postkomunistycznych (a także na Cyprze), a najwięcej - w Skandynawii, krajach Beneluksu i na Wyspach Brytyjskich.

Także dane niemieckie pokazuja, że mimo upływu lat aktywność mieszkańców postkomunistycznych landów wschodnich była na początku XXI w. wyraźnie niższa niż mieszkańców landów zachodnich. W 2001 r. do jakiejśs organizacji społecznej należało 48,6\% Niemców zachodnich i 41,7\% Niemców wschodnich, w wolontariacie udzielało się odpowiednio $16 \%$ i $12 \%$, a do partii politycznej należało odpowiednio $3,1 \%$ i $2 \%{ }^{18}$.

\section{Badania porównawcze: Polska 1989-2013}

Badania własne z 1992 r. (przeprowadzone wyłącznie w województwach zielonogórskim i poznańskim) pokazały, że odsetek osób należących do jakichkolwiek stowarzyszeń (a zwłaszcza związków zawodowych) był w III RP znacznie niższy niż w PRL ${ }^{19}$. Pytania w tym badaniu były formułowane na wzór badania brytyjskiego ${ }^{20}$, co umożliwiało przy okazji porównanie obu tych tak odmiennych oczywiście społeczeństw.

Tabela 5

Przynależność do stowarzyszeń i organizacji w Polsce i Wielkiej Brytanii w latach osiemdziesiątych i dziewięćdziesiątych XX w. [\%]

\begin{tabular}{|l|c|c|c|}
\hline \multirow{2}{*}{ Organizacja } & \multicolumn{2}{c|}{ Polska } & \multirow{2}{*}{ Wielka Brytania } \\
\cline { 2 - 3 } & $\mathbf{1 9 9 2}$ & $\begin{array}{c}\text { Przed } \\
\mathbf{1 9 8 9}\end{array}$ & $\begin{array}{c}\mathbf{1 9 8 5}-\mathbf{1 9 8 6} \\
\text { Związek zawodowy }\end{array}$ \\
\cline { 2 - 3 } & 13,0 & 30,0 & 27,0 \\
\hline Klub hobbystów, klub sportowy & 14,4 & 25,3 & 24,3 \\
\hline Stowarzyszenie profesjonalne, izba, związek & 6,8 & 7,5 & 8,4 \\
\hline Organizacja religijna, kościelna, parafialna & 3,0 & 4,7 & 19,4 \\
\hline Samorząd mieszkańców, rada osiedla & 2,2 & 3,0 & 6,4 \\
\hline Partia polityczna & 1,0 & 7,7 & 6,8 \\
\hline
\end{tabular}

Źródło: K. Podemski, op. cit.; G. Parry, G. Moyser, N. Day, op. cit.

Według naszych badań w 1992 r. do żadnej organizacji nie należało aż 63\% mieszkańców Wielkopolski i Ziemi Lubuskiej, podczas gdy badania brytyjskie wykazywały, że jedynie 27\% Brytyjczyków nigdzie nie należy.

18 Zob. http://www.gesis.org/en/publications/archive/data-report/.

19 K. Podemski, Uczestnictwo w życiu publicznym, w: M. Ziółkowski, B. Pawłowska, R. Drozdowski (red.), Jednostka wobec władzy, Nakom, Poznań 1994.

${ }^{20}$ G. Parry, G. Moyser, N. Day, Political Participation and Democracy in Britain, Cambridge University Press, Cambridge 1992. 
Do trzech i więcej stowarzyszeń należało 20\% Brytyjczyków, ale jedynie 1\% Polaków zamieszkujacych dwa badane województwa.

Przypomnijmy, że dane porównawcze pochodzące z badań z lat 1990 i 1999 (tab. 1) pokazuja, że odsetek osób deklarujących przynależność organizacyjną lub jakaśs formę aktywności na rzecz organizacji zmalał w ciagu dekady. O ile w 1990 r. jedynie 55\% badanych deklarowało, że nigdzie nie należy, o tyle w 1999 r. osoby takie stanowiły już 75\%. Z 66 do 86\% wzrósł także odsetek osób, które nie angażowały się w żadne działania obywatelskie, niekoniecznie formalne. Największy ubytek członków odnotowały związki zawodowe - z 21 do $17 \%$, ale mimo wszystko pozostały i tak najbardziej „masową” forma stowarzyszenia.

Raporty z największego polskiego badania sondażowego pokazuja, że aktywność obywatelska obejmowała zaledwie kilkanaście procent Polaków i w ostatniej dekadzie nie ulegała większym zmianom.

\section{Tabela 6}

Aktywność obywatelska Polaków 2003-2013, Diagnoza społeczna [\%]

\begin{tabular}{|l|r|r|r|r|r|r|}
\hline \multicolumn{1}{|c|}{ Aktywność } & $\mathbf{2 0 0 3}$ & $\mathbf{2 0 0 5}$ & $\mathbf{2 0 0 7}$ & $\mathbf{2 0 0 9}$ & $\mathbf{2 0 1 1}$ & $\mathbf{2 0 1 3}$ \\
\hline Członkowie organizacji & 12,2 & 12,1 & 15,1 & 13,2 & 14,8 & 13,7 \\
\hline Pełniący funkcje w organizacjach & 5,3 & 6,8 & 6,3 & 5,0 & 4,8 & 6,3 \\
\hline $\begin{array}{l}\text { Właczajacy się w działania na rzecz } \\
\text { społeczności }\end{array}$ & 12,9 & 13,6 & 14,1 & 15,6 & 15,6 & 15,2 \\
\hline $\begin{array}{l}\text { Udział w zebraniu publicznym poza } \\
\text { miejscem pracy }\end{array}$ & 18,5 & 19,0 & 20,3 & 19,0 & 22,6 & 17,0 \\
\hline
\end{tabular}

Źródło: opracowanie własne na podstawie Diagnoza społeczna 2013. Warunki i jakość życia Polaków, red. J. Czapiński, T. Panek, WSFiZ, Warszawa 2013.

Według pierwszego z serii raportu Diagnoza społeczna $2003^{21}$ jedynie $12,3 \%$ badanych przyznało się do członkostwa w jakiejś „organizacji, stowarzyszeniu, partii, komitecie, radzie, związku lub grupie religijnej”, przy tym 10,3\% zadeklarowało, że należy tylko do jakiejś jednej organizacji, 1,6\% - że należy do dwóch, a 0,4\% - do trzech lub więcej, w 2013 r. deklarowało tak odpowiednio 10,3\%, 2,5\% i 0,9\%. Jak łatwo przewidzieć, współczynnik zrzeszania się był różny w różnych kategoriach społecznych. Najbardziej go różnicowało wykształcenie. Wśród osób z wykształceniem wyższym w 2003 r. należało do jakiejśs organizacji 25\%, a wśród osób z wykształceniem podstawowym jedynie 7,5\% (w 2013 było to odpowiednio 15,7\% i 4,7\%). Zamożni zrzeszali się częściej niż biedni, mężczyźni częściej niż kobiety, osoby w wieku średnim i starszym częściej od młodych, mieszkańcy miast częściej niż mieszkańcy miasteczek i wsi. Mieszkańcy regionów z tradycjami obywatelskimi (dawna Ga-

${ }^{21}$ Diagnoza społeczna 2003. Warunki i jakość ̇̇ycia Polaków, red. J. Czapiński, T. Panek WSFiZ, Warszawa 2004; A. Sułek, Stan społeczeństwa obywatelskiego w Polsce, w: ibidem. 
licja, Wielkopolska, Śląsk Opolski) stowarzyszają się częściej niż mieszkańcy dawnego zaboru rosyjskiego i ziem zachodnich. Odsetek osób stowarzyszonych był w 2003 r. niemal dwukrotnie wyższy w województwie opolskim $(15,7 \%)$ niż w zachodniopomorskim (8,2\%). W 2013 r. najczęściej zrzeszeni byli pracownicy sektora samorządowego $(27,2 \%)$, a najmniej bezrobotni $(6,1 \%)$ i inni bierni zawodowo (9,6\%). W 2013 r. spośród osób należących do jakiegoś stowarzyszenia (13,1\%) stosunkowo najwięcej osób deklarowało przynależność do organizacji religijnej (23,9\%), klubu sportowego (15,3\%), koła zainteresowań $(13,7 \%)$, związu zawodowego $(11,7)$, organizacji towarzyskiej $(9,5 \%)$, komitetu rodzicielskiego $(8,1 \%)$, organizacji pomagającej $(7,8 \%)$, komitetu mieszkańców (6,7\%) i organizacji zawodowej lub branżowej (6,5\%), mniej do organizacji upowszechniających wiedzę $(4,9 \%)$, partii politycznej $(3,2 \%)$, organizacji ekologicznej (2,9\%), do władz samorządowych (2,7\%), organizacji samopomocowej $(1,8)$, a najmniej do organizacji konsumentów $(0,4 \%)$. Do innych niż wymienione należało $22 \%$ z tych, którzy byli członkami jakiegokolwiek stowarzyszenia.

Jak podsumowują swój ostatni raport o stowarzyszaniu się autorzy, Polacy „Nie umieja, bo nie działaja, a nie działaja, bo nie umieją - jest to błędne koło działań dla społeczności”22.

Z uczestnictwem w życiu publicznym łączy się przekonanie o tym, że posiada się jakiśs przynajmniej wpływ na bieg wydarzeń. Ten wątek z kolei był regularnie badany przez CBOS.

Pokazuje on rosnace poczucie wpływu, przede wszystkim na losy swojej społeczności lokalnej. To chyba najbardziej „optymistyczny” wskaźnik rozwoju społeczeństwa obywatelskiego. Odsetek badanych, którzy takie poczucie deklarowali, rósł od 16\% w 1992 r. do 52\% w „rekordowym” 2010 r. Od tego czasu maleje.

Tabela 7

Poczucie wpływu na sprawy swojego miasta, gminy [\%]

\begin{tabular}{|l|c|c|c|c|c|c|c|c|c|c|}
\hline $\begin{array}{l}\text { Odpowiedź } \\
\text { respondentów }\end{array}$ & $\mathbf{1 9 9 2}$ & $\mathbf{1 9 9 7}$ & $\mathbf{1 9 9 9}$ & $\mathbf{2 0 0 4}$ & $\mathbf{2 0 0 7}$ & $\mathbf{2 0 0 8}$ & $\mathbf{2 0 0 9}$ & $\mathbf{2 0 1 0}$ & $\mathbf{2 0 1 2}$ & $\mathbf{2 0 1 3}$ \\
\hline Tak & 16 & 26 & 25 & 34 & 42 & 39 & 42 & 52 & 50 & 42 \\
\hline Nie & 79 & 69 & 73 & 63 & 54 & 58 & 55 & 45 & 47 & 56 \\
\hline $\begin{array}{l}\text { Trudno } \\
\text { powiedzieć }\end{array}$ & 5 & 5 & 2 & 3 & 4 & 2 & 3 & 3 & 3 & 2 \\
\hline
\end{tabular}

Źródło: Dwadzieścia lat przemian ustrojowych w Polsce, CBOS, Warszawa 2009; K. Pankowski, Poczucie wplywu na sprawy publiczne, Komunikat BS/121/2013, CBOS, Warszawa 2013.

Znacznie słabiej rosło poczucie wpływu obywateli na sprawy kraju: od 7\% w 1992 r. do 36\% w 2010 r. Również w tym przypadku ten rok okazał się cezura, nawet jeszcze bardziej wyraźna, ponieważ w 2013 r. odsetek ten zmniejszył się w porównaniu z rekordowym 2010 niemal o połowę.

${ }^{22}$ Diagnoza społeczna 2013, op. cit., s. 284. 
Tabela 8

Poczucie wpływu na sprawy kraju [\%]

\begin{tabular}{|l|c|c|c|c|c|c|c|c|c|c|}
\hline $\begin{array}{l}\text { Odpowiedź } \\
\text { respondentów }\end{array}$ & $\mathbf{1 9 9 2}$ & $\mathbf{1 9 9 7}$ & $\mathbf{1 9 9 9}$ & $\mathbf{2 0 0 4}$ & $\mathbf{2 0 0 7}$ & $\mathbf{2 0 0 8}$ & $\mathbf{2 0 0 9}$ & $\mathbf{2 0 1 0}$ & $\mathbf{2 0 1 2}$ & $\mathbf{2 0 1 3}$ \\
\hline Tak & 7 & 19 & 11 & 15 & 24 & 30 & 25 & 36 & 30 & 19 \\
\hline Nie & 91 & 76 & 87 & 83 & 73 & 65 & 72 & 60 & 68 & 79 \\
\hline $\begin{array}{l}\text { Trudno powie- } \\
\text { dzieć }\end{array}$ & 2 & 4 & 5 & 2 & 3 & 5 & 3 & 4 & 2 & 2 \\
\hline
\end{tabular}

Źródło: Dwadzieścia lat przemian ustrojowych w Polsce, op. cit.; K. Pankowski, op. cit.

Według badań CBOS-u poczucie wpływu mają częściej osoby należące do jakichś organizacji, lepiej wykształcone, zamożniejsze i młodsze. Mieszkańcy wielkich miast mają większe poczucie wpływu na sprawy kraju, ale, co zrozumiałe, mniejsze na sprawy swoich lokalnych społeczności. Jednocześnie zdecydowanej większości Polaków zależy raczej na tym, aby „nimi dobrze rządzono” (79\% w 2001, 78\% w 2009), niż „by uczestniczyć w rządzeniu” (odpowiednio 16\% i 17\%). Ponownie częściej chęć udziału w rządzeniu wyrażali młodsi, poniżej 44 lat $^{23}$.

W minionym roku CBOS badało także zaangażowanie obywateli w sprawy społeczności lokalnej. Aż trzy czwarte badanych nie zadeklarowało żadnej formy uczestnictwa.

\section{Tabela 9}

Osobiste zaangażowanie w sprawy społeczności lokalnej

\begin{tabular}{|l|c|}
\hline \multicolumn{1}{|c|}{ Działanie } & $\%$ \\
\hline Współorganizowanie imprez lokalnych na rzecz społeczności & 9 \\
\hline $\begin{array}{l}\text { Bezpośredni kontakt z urzędnikiem w jakiejś sprawie dotyczącej społeczności } \\
\text { lokalnej }\end{array}$ & 8 \\
\hline $\begin{array}{l}\text { Bycie wolontariuszem, wykonywanie jakiejś bezpłatnej pracy na rzecz } \\
\text { społeczności lokalnej lub organizacji }\end{array}$ & 5 \\
\hline $\begin{array}{l}\text { Bezpośredni kontakt z radnym lub lokalnym politykiem pełniącym urząd lub } \\
\text { kandydującym do niego }\end{array}$ & 4 \\
\hline $\begin{array}{l}\text { Działalność w organizacji kościelnej/parafii (poza uczestnictwem w obrzędach } \\
\text { religijnych) }\end{array}$ & 4 \\
\hline Działalność w organizacji społecznej, pozarządowej & 4 \\
\hline Aktywny udział w konsultacjach społecznych & 2 \\
\hline Kontaktowanie się z mediami po to, aby zainteresować je jakąś sprawą & 75 \\
\hline Żadne z wymienionych & 6 \\
\hline
\end{tabular}

Źródło: K. Pankowski, op. cit.

${ }^{23}$ Dwadzieścia lat przemian ustrojowych w Polsce, op. cit. 


\section{KONKLUZJE}

Zainteresowanie obywateli uczestnictwem w życiu publicznym w krajach cywilizacji zachodniej generalnie od kilkunastu lat maleje. Jest to rezultatem globalizacji, która powoduje, że coraz mniej kwestii zależy od wybranych demokratycznie władz państwowych, a coraz więcej od globalnych korporacji i organizacji. Wpływ obywateli na bieg wydarzeń staje się zatem coraz bardziej iluzoryczny, czego świadomość rośnie. Nie bez znaczenia są najpewniej inne procesy, takie jak komercjalizacja, która powoduje zamianę obywateli w konsumentów, czy medializacja polityki, która ogranicza alternatywność wyborów programowych na rzecz wyborów wykreowanych osobowości i sloganów. Procesy te powodują wycofywanie się obywateli ze sfery publicznej, w tym także spadek udziału w wyborach. Kraje europejskie różnią się stopniem udziału obywateli w sprawach publicznych. W niektórych, np. w Szwecji czy Holandii, odsetek obywateli stowarzyszonych i aktywnych stale rośnie. Wiele zależy od tradycji i kultury politycznej danego kraju.

Najniższy stopień uczestnictwa odnotowuje się w krajach postkomunistycznych. Gdyby porównać przynależność do organizacji i frekwencję wyborczą w tych krajach, można by odnieść wrażenie, że społeczeństwo obywatelskie przed transformacją funkcjonowało lepiej. Takie wnioski są oczywiście nieuprawnione, ponieważ w krajach komunistycznych przynależność do rozmaitych organizacji politycznych, związków zawodowych czy nawet, jak w Polsce do PCK, była przynajmniej dobrze widziana. Podobnie było z wyborami. Jednym $\mathrm{z}$ powodów niższego uczestnictwa $\mathrm{w}$ tych krajach może być zatem pamięć tego przymusu i traktowanie absencji wyborczej i braku członkostwa w organizacjach społecznych jako gestu „wolnościowego”. Innym powodem jest ukształtowany w nich odmienny typ kultury politycznej. Społeczeństwa te nie doświadczyły tak ważnych etapów rozwoju społeczeństwa obywatelskiego, jak angielska czy francuska rewolucja mieszczańska czy zachodnioeuropejskie i amerykańskie kontrkultury. Nowe, postkomunistyczne społeczeństwa obywatelskie mogły budzić się dopiero wtedy, gdy zainteresowanie uczestnictwem w krajach „starej” Europy zaczęło maleć.

Zgodnie z przytoczonym na początku stanowiskiem Sartoriego, nie zajmuje się tu problemem frekwencji wyborczej, ale warto wspomnieć, że generalnie frekwencja wyborcza jest w Polsce niższa od średniej europejskiej o około $20 \%{ }^{24}$.

O widocznej publicznej apatii w naszym kraju mówią nam nie tylko badania socjologiczne i sondaże, lecz także potoczne doświadczenie. W szkołach od lat z powodu braku chętnych trudno jest wybrać tzw. trójki klasowe. W wyborach do samorządu studenckiego uczestniczy niewielki odsetek studentów, a na uczelniach prawie nieobecne sa organizacje studenckie. Wybory do tzw. samorządów pomocniczych w większych miastach osiagają jednocyfrowa frekwencję. Demonstracje przeciwko udziałowi w wojnie w Iraku i Afganistanie, gromadzące w Paryżu czy Madrycie setki tysięcy mieszkańców, w Polsce liczyły sobie najwyżej kilkudziesięciu uczestników, z reguły wywodzących się

${ }^{24}$ J. Szawiel, op. cit. 
z uznawanego za skrajne środowiska anarchistycznego. Podobnie jak szerszy ruch pacyfistyczny czy alterglobalistyczny, nie istnieje także w Polsce w zasadzie ruch konsumencki. Tę sferę niemal całkowicie wypełniają instytucje publiczne, takie jak rzecznicy praw konsumenta. Pewnym novum sa opisywane ostatnio w mediach warszawskie hipsterskie kooperatywy zaopatrujace członków w żywność ekologiczna. Z tzw. nowych ruchów społecznych względnie, jak na nasze warunki, prężnie działają od niespełna kilku lat organizacje ekologiczne i organizacje LGBT. Do działań wspólnotowych (o bardzo różnym charakterze) w szerszej skali, choć z reguły na krótki okres, udaje się w Polsce zmobilizować masy chyba tylko centralom związkowym, Radiu Maryja oraz człowiekowi - instytucji Jurkowi Owsiakowi. Dwie pierwsze instytucje dysponują jednak trwałymi ogólnopolskimi scentralizowanymi strukturami (zakładowe organizacje związkowe, parafie), a druga z nich jest sama wpływowym medium bezpośrednio mobilizującym wiernych mu słuchaczy. Z kolei Wielka Orkiestra Świątecznej Pomocy korzysta z szerokiego wsparcia centralnych i lokalnych mediów, które bezpośrednio angażują się w organizację corocznej wielkiej akcji charytatywnej.

Dodać należy, że w ostatnich latach pojawiły się rozmaite nowe zjawiska. Po pierwsze, ruch smoleński, uosabiany najpierw przede wszystkim przez tzw. obrońców krzyża na Krakowskim Przedmieściu, a później przez comiesięczne demonstracje oraz powstałe kluby „Gazety Polskiej”.

Po drugie, mamy do czynienia z odrodzeniem się ruchu nacjonalistycznego, przenikaniem się tego ruchu ze środowiskiem kibiców i nadawaniem przez jego liderów nowych znaczeń obchodom narodowych rocznic, zwłaszcza Świętu Niepodległości. W obu przypadkach (ruch smoleński, ruch nacjonalistyczno-kibicowski) mamy jednak raczej nie tyle do czynienia z samoorganizujacym w celu rozwiązania jakichś problemów społeczeństwem obywatelskim, ile raczej, by odwołać się do cytowanego już Norwida, ze zorientowanym na przeszłość rebelianckim „narodowym sztandarem”. Podobny charakter ma także część działań zbiorowych koordynowanych przez Radio Maryja. Nadal więcej ludzi w Polsce można zmobilizować do wyjścia na ulice pod narodowym hasłem Bóg, Honor, Ojczyzna niż pod obywatelskim Liberté, Egalité, Fraternité czy kontrkulturowym Zabrania się zabraniać.

Po trzecie, pojawiają się nowe zjawiska związane z możliwościami szybkiego mobilizowania zainteresowanych przez portale społecznościowe. Najbardziej znane przykłady to kontrdemonstracja „Akcja Krzyż” w sierpniu 2010 r. na Krakowskim Przedmieściu oraz odbywające się zimą 2012 r. w wielu polskich miastach parodniowe demonstracje przeciwko tzw. ustawom ACTA. Ten ostatni przypadek jest szczególnie interesujący, ponieważ to polska młodzież była pionierem tych protestów w Europie. Demonstracje te odbiły się głośnym echem i obudziły wiele nadziei. Postrzegano je bowiem jako początek tworzenia się nowej postaci ruchu społecznego „pokolenia sieci” ${ }^{25}$. Dwa lata po tych wydarzeniach trzeba chyba uznać, że była to ocena pochopna. Nie ma watpliwości natomiast, że Internet czyni niesłychanie łatwą tę formę publicznego uczestnictwa, jaka jest podpisywanie petycji. Istnieja w tej chwili wyspecja-

${ }^{25}$ E. Bendyk, Bunt sieci, Biblioteka Polityki, Warszawa 2012. 
lizowane portale umożliwiające tworzenie i podpisywanie petycji, z których najbardziej popularne to www.petycje.pl oraz www.petycjeonline.com/. Petycje te dotycza rozmaitych sfer. Od kontrowersyjnych spraw publicznych, przez popieranie lokalnych inwestycji, do domagania się kontynuacji popularnych seriali telewizyjnych lub organizacji koncertów gwiazd muzyki popularnej. Wielość tych petycji prowadzi do ich dewaluacji jako aktu obywatelskiego, czego dowodem jest także fakt, że niewiele z nich spotyka się z jakąś reakcja adresatów. Internet daje ogromne unikatowe w dziejach ludzkości możliwości nawiązywania kontaktów, wymiany opinii, wypowiadania się publicznego poprzez blogi i udział $\mathrm{w}$ forach oraz, na razie ciagle bardzo potencjalnie, organizowania się, raczej ad hoc, jak w przypadku flashmobów czy hakerskich ataków. Wyjątkiem są oczywiście sytuacje rewolucyjne, jak arabska wiosna czy ukraiński Euromajdan. Można ewentualnie przyjąć, że tematyczne, problemowe, hobbystyczne czy polityczne portale są też formami „stowarzyszania” się, jednak bardzo płynnymi i mało zobowiąujaccymi, raczej dyskusyjnymi niż prowadzącymi wspólne działania.

Po czwarte, z większym odzewem niż jeszcze kilka lat temu spotykają się próby wywierania wpływu poprzez referenda. Zarówno akcja odwoływania prezydent Warszawy, jak i akcja blokowania ustawy o nauczaniu sześciolatków, choć nie przyniosły oczekiwanych przez organizatorów skutków, bez watpienia doprowadziły do masowej obywatelskiej mobilizacji. Trudno w tej chwili powiedzieć, czy jest to zapowiedź jakiejś zmiany. Wydaje się, że głęboki podział polskich elit symbolicznych i politycznych sprzyja pewnym formom mobilizacji społecznej, tym związanym bardziej bezpośrednio ze sfera polityki i ideologii. Z drugiej strony bez watpienia inne jej formy, które wymagają działania ponad podziałami, blokuje.

Po piąte, problematyka partycypacji jest coraz bardziej obecna w publicznym dyskursie. Wyrazem tego sa m.in. coraz liczniejsze, a do niedawna prawie nieobecne na naszym rynku - przewodniki (i antyprzewodniki) partycypacji ${ }^{26}$. Po szóste, pojawiają się rozmaite lokalne inicjatywy partycypacyjne i konsultacyjne, w tym bardzo ostrożne i bardzo ograniczone próby wprowadzania budżetu obywatelskiego, m.in. w Sopocie i Poznaniu ${ }^{27}$.

Po szóste, od paru lat rozwijają się w większych miastach ruchy miejskie. W wyborach lokalnych w 2010 r. pionierski ruch My-Poznaniacy przedstawił kandydata na prezydenta miasta i kandydatów do rady miasta, finalnie uzyskując niemal 10\% głosów. Ruchy te podejmują próby koordynacji. Do tej pory odbyły się trzy kongresy ruchów miejskich. Ich oddziaływanie na miejskie polityki wydaje się większe, niż wynikałoby to z ich liczebności, gdyż z reguły należy do nich najwyżej kilkadziesiąt osób.

W ten sposób dochodzimy do głównej tezy artykułu: 25 lat po transformacji polskie społeczeństwo obywatelskie ma charakter elitarny, a nie

${ }^{26}$ P. Sadura, J. Erbel (red.), Partycypacja. Przewodnik Krytyki Politycznej, Wydawnictwo Krytyki Politycznej, Warszawa 2012.

${ }^{27}$ R. Drozdowski, M. Frąckowiak, Bilans społecznej wyobraźni. Komentarz socjologiczny do poznańskiego budżetu obywatelskiego, „Ruch Prawniczy, Ekonomiczny i Socjologiczny” 2013, z. 4; M. Milewicz, K. Podemski, Konsultacje czy manipulacja?, w: P. Sadura, J. Erbel (red.), op. cit. 
masowy. Istnieje wiele organizacji i stowarzyszeń wypełniajacych różne, zarówno tradycyjne, jak i nowe, obywatelskie pola, często te same co w krajach o dużych tradycjach obywatelskich. Problem tkwi w tym, że w przeciwieństwie do tamtych społeczeństw mają one wyłącznie charakter kadrowy, sa słabo zakorzenione społecznie. W badaniach sondażowych są w związku z tym niezauważalne. Wywierają jednak, dzięki mediom, znacznie większy wpływ na życie publiczne, niż wskazywałaby na to ich liczebność. Przynależność do stowarzyszeń i inne formy obywatelskiej aktywności, takie jak podpisywanie petycji, zabieranie publicznie głosu, udział w demonstracjach, nie sa jeszcze elementem polskiej kultury politycznej. Pewne nadzieje może budzić fakt, że ludzie młodzi mają większe poczucie wpływu na rzeczywistość, a to jego brak jest jedną z barier rozwoju społeczeństwa obywatelskiego. Aktywność obywatelską moga im ułatwić media społecznościowe.

$\mathrm{Na}$ kilka powodów, zarówno globalnych, jak i specyficznych dla krajów postkomunistycznych, słabości społeczeństwa obywatelskiego w Polsce zwracałem już tu uwagę. Na koniec chciałbym wymienić kilka bardziej lokalnych uwarunkowań tego procesu.

Po pierwsze, neoliberalna narracja lat 1989-2008, propaganda indywidualizmu ekonomicznego szybko wyparły zaraz na początku transformacji z publicznego dyskursu ideę społeczeństwa obywatelskiego rozwijaną w koncepcji Samorządnej Rzeczypospolitej I Zjazdu NSZZ „Solidarność”, w poglądach Jacka Kuronia i Stefana Bratkowskiego oraz w praktyce Komitetów Obywatelskich.

Po drugie, pojawiajace się na początku transformacji oddolne inicjatywy obywatelskie (jak np. lokalne ruchy obywatelskie, lokalne media, stowarzyszenia oświatowe i in.) bardzo często przegrywały z państwem albo z rynkiem. Ulegały upartyjnieniu, biurokratyzacji lub komercjalizacji.

Po trzecie, dezintegracja i dekompozycja społeczna. Znika klasa robotnicza, a wraz z nią i związki zawodowe. Przeobrażają się wieś i warstwa chłopska, co sprzyja zanikowi tradycyjnych wiejskich form stowarzyszania się. Dekompozycji ulega także inteligencja, czemu towarzyszy ograniczenie roli np. takich form, jak choćby istniejące od październikowej odwilży Kluby Inteligencji Katolickiej. Nowa klasa średnia dopiero się rodzi i nie przystępuje masowo do powstałych po $1989 \mathrm{r}$. organizacji biznesowych i charytatywnych.

Po czwarte, wysoki poziom bezrobocia nie sprzyja rozwojowi cnót obywatelskich. Sa takie regiony, gdzie lokalny przedsiębiorca jest quasi-feudalnym panem w stosunku do mieszkańców i skutecznie blokuje jakiekolwiek formy ich stowarzyszania się przeciwko takiej hegemonii. Dobrą ilustracją tego zjawiska były dramatyczne próby przeciwstawienia się wszechwładzy senatora i potentata Henryka Stokłosy w województwie pilskim.

Po piąte, działalność publiczna nie jest w naszym społeczeństwie oceniana wysoko. Dotyczy to nie tylko sfery politycznej, lecz także sfery obywatelskiej, społecznej, pro publico bono. Jak w innych krajach postkomunistycznych cenione są raczej przymioty, które umożliwiały przeżycie w opresyjnym systemie i gospodarce niedoboru: oportunizm, cwaniactwo, postawa wyrażana w powiedzeniach „Głową muru nie przebijesz” i „Nie krytykuj, nie podskakuj, siedź na d.... i przytakuj”. 
Po szóste, „próżnię stowarzyszeniową" wypełniają w Polsce intensywne i rozgałęzione kontakty rodzinne, co jest charakterystyczną cechą społeczeństw tradycyjnych. Mają one w znacznej mierze charakter nepotycznych sieci. W przeciwieństwie do obywatelskich stowarzyszeń nie wstępuje się do nich, lecz należy z racji urodzenia.

Po siódme, słabość niektórych ruchów ma w Polsce swoje szczególne przyczyny. Na przykład dominacja jednej religii, a zatem brak konkurencji między różnymi wyznaniami, nie sprzyja rozwojowi jakichkolwiek inicjatyw obywatelskich w tej sferze, mimo że Polska należy do najbardziej religijnych krajów Europy. Być może narastające konflikty między hierarchią a wiernymi zmienią tę sytuację, o czym mogłaby świadczyć akcja parafian w obronie ks. Lemańskiego. I w tym przypadku jednak udział „czynnika zewnętrznego”, czyli centralnych mediów, w tej mobilizacji był bardzo znaczący.

dr hab. Krzysztof Podemski

Profesor Uniwersytetu im. Adama Mickiewicza w Poznaniu

podemski@amu.edu.pl

CIVIL SOCIETY IN POLAND 25 YEARS AFTER THE GREAT CHANGE

Summary

This paper is an attempt to present the evolution and the condition of the civil society in Poland 25 years after the transformation of the political regime. The analysis is based on the existing results of earlier research and on the author's own studies and observations. It also refers to the discourse that has been going on in Poland since the middle of the nineteenth century on the difficulties in building a Polish civil society. As the analysis shows, Poles do indeed, affiliate much less frequently than citizens in West European states, or, even in comparison with citizens of other post-communist states. Another Polish specificity is that although there is a variety of organisations and associations, also representing followers of new social movements, most of them are elite in character. Membership in organisations does not have a mass character in Poland, nor is an element of political culture. Social networks may, eventually, facilitate communication and collaboration in social matters. Their role today, however, is negligible. 
Copyright of Journal of Law, Economics and Sociology is the property of Faculty of Law and Administration of Adam Mickiewicz University in Poznan and its content may not be copied or emailed to multiple sites or posted to a listserv without the copyright holder's express written permission. However, users may print, download, or email articles for individual use.

Właścicielem praw autorskich do „Ruchu Prawniczego, Ekonomicznego i Socjologicznego” jest Wydział Prawa i Administracji Uniwersytetu im. Adama Mickiewicza w Poznaniu. Zawartość czasopisma nie może być kopiowana, przesyłana do innych stron internetowych bądź zamieszczana na blogach bez pisemnej zgody wydawcy. Niemniej artykuły można drukować, kopiować lub przesyłać w formie elektronicznej na własny użytek. 